\title{
internationapournal
}

\section{of critical indigenous studies}

\section{International Journal of Critical Indigenous Studies}

Volume 13, Number 2, 2020

\section{A review of Nyoongar responses to severe climate change and the threat of epidemic disease-Lessons from their past}

Authors

Francesca Robertson and Jason Barrow

\section{About the authors}

Dr Francesca Robertson is a Senior Research Officer at Kurongkurl Katitjin, Centre for Indigenous Australian Education and Research, Edith Cowan University. Dr Robertson is a social worker and family therapist with decades of practice with marginalised families, many of whom were Aboriginal. She is also a teacher and researcher and has published a number of papers and books on the deep history of Aboriginal people.

Jason Barrow is a Nyoongar man from the South West of Western Australia. For many years, he was a Cultural Awareness Officer at Kurongkurl Katitjin, delivering and sharing his Nyoongar knowledge and ways of working, especially through Edith Cowan University's Old Ways New Ways program. He is co-chair for the Indigenous Advisory Group of the Clean Air and Urban Landscapes hub of the National Environmental Science Program.

\section{Abstract}

Nyoongar people have lived in the South West of Western Australia for at least 50,000 years. During that time, they experienced significant climate change, including wide variations in temperature and rainfall, and hundreds of metres' difference in sea levels. Nyoongar people have a long memory, and climate change is described in their stories and in the knowledge they hold about how life was lived in earlier times. There are artifacts and places that have been manipulated to be productive despite severe drought. COVID-19 disrupted the writing of this article, and the authors felt it appropriate to include Nyoongar responses to the threat of epidemic disease brought by Europeans early in their settlement of the area. This review collates existing material generated through Koodjal Jinnung (two-way seeing), a research method that incorporates traditional knowledge and contemporary social and natural sciences about Nyoongar history, to create a description of the resiliency of Nyoongar people under threat from climate change. The article identifies key values and resilience factors underpinning the successful implementation of behavioural and technological mechanisms to negotiate severe climate change and the threat of epidemic disease.

\section{Keywords}

climate change, Nyoongar, Aboriginal, deep history, epidemic disease

Except where otherwise noted, content in this journal is licensed under Creative Commons Attribution 4.0 International Licence. As an open access journal, articles are free to use with proper attribution. ISSN 1837-0144

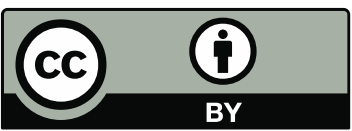

(C) The Author(s) 2020 https://doi.org/10.5204/ijcis.v13i1.1638 
Nyoongar people are the Aboriginal inhabitants of the southwestern corner of the state of Western Australia (WA). Nyoongar boodja (land) extends north-south from Geraldton to Israelite Bay and west-east from the coast to the eastern wheatbelt. The land forms a triangle, with the western and southern borders being coastline. Archaeologists have identified evidence of human occupation across Nyoongar boodja:

People occupied the Derbyl Yerrigan (Swan River system) 40,200 to 49,000 years ago (O'Connell \& Allen, 2012) and were on Wadjemup (Rottnest Island) when it was still part of the mainland 50,000 years ago (Hesp, Murray-Wallace, \& Dortch, 1999). Nyoongars were camped around Wooditchup (Margaret River) as far back as 48,000 years ago (Turney et al., 2001b). People occupied the caves east of Yincular (Eucla) between 40,000 and 43,000 years ago (Roberts et al., 1996 and Turney, Bird, Fitfield et al., 2001). (Robertson, Nannup, \& Barrow, 2019, p. 15)

Most Nyoongar people were isolated from European settlers until after the 1830s, and some Nyoongar people were living a traditional life until the 1900s. Although wounded by successive waves of destructive government policies, and still affected by the legacy of the Stolen Generations, Nyoongar traditional knowledge and language is largely intact.

Nyoongar people experienced a stable ecology for the first 15,000 years of occupation and then a gradual drying and cooling period leading to 10,000 years of extraordinarily severe drought and cold between 25,000 and 15,000 years ago. This was followed by a relatively rapid rise in temperature and rainfall and a long stable period prior to European colonisation. Since the beginning of Nyoongar occupation, the coastline at the climatic extremes varied between $4 \mathrm{~m}$ above and $400 \mathrm{~m}$ below its current position. The eastern edge of Nyoongar boodja was also a shifting border-during the extremely dry periods, the desert would have significantly encroached on it.

Settlers began arriving in Nyoongar territory in 1826, but they failed to thrive at first. Between 1848 and 1889, a large number of the poorest people arrived, gathered from Irish and British prisons and workhouses (Taylor, 1981). Census figures from the WA government summarised in 2004 and population cohort analysis indicates that by 1868 there were just over 24,000 non-Aboriginal people in WA, with a gender imbalance of two men for every woman. Those settling outside Nyoongar boodja passed through it, using ports at Kalingiri (Albany), Coombarnup (Bunbury) and Walyalup (Fremantle). It was largely these men and the sons of these women who, predominantly as rapists, impregnated Nyoongar and other Aboriginal women. The Nyoongar community was exposed to myriad diseases against which they had no immunity.

There are two factors that enhance the significance of Nyoongar adaptations to climate change that are different to the experience of people living elsewhere on the planet. First, significant climate change between 25,000 and 15,000 years ago made large areas uninhabitable. Nyoongar boodja remained habitable and was occupied throughout the last 48,000 years (Turney, Bird, \& Roberts, 2001; Veth, 1995). Second, climate change in other areas diminished resources and humans resorted to fighting. No archaeologist has found evidence of fighting or famine in response to the diminished resources that occurred in WA. There is also a significant difference in behaviour in response to children conceived outside traditional marriage laws. For example, wherever the British colonised they created a "mixed-race" cohort. In many places this cohort became and remains self-defining, being, for example, Anglo-Indian or Anglo-Burmese. This cohort distinction arose because anecdotally they were rejected by both parent races. In Nyoongar boodja, such children were typically rejected by colonisers but not by Nyoongar people. 
This article is a review of material that shows the values, behaviours and technology inherent in the capacity of the Nyoongar community to maintain its functioning during periods of significant ecological challenge.

\section{Methodology}

The research projects from which this article draws were all conducted using Koodjal Jinnung (looking both ways), a research method developed at Kurongkurl Katitjin, Centre for Australian Aboriginal Education and Research at Edith Cowan University. Koodjal Jinnung generates new knowledge by simultaneously exploring a theme through Aboriginal and contemporary Western lenses (Robertson, Nannup, Stasiuk, \& Hopper, 2017). The two knowledge sets are compared and contrasted so the resonances and dissonances are highlighted and begin to inform each other. As a variant of participatory action research, it builds theory through processes of observation, reflection and collaboration (Kemmis \& McTaggart, 2005; MacNaughton, 2001). The inclusive, reflexive and emancipatory nature of this research makes it ideally suited to the generation of contemporary interpretations of ancient knowledge.

Projects using Koodjal Jinnung informing this article include: "Old Ways, New Ways" (www.ncsehe.edu.au/old-ways-new-ways/), which delivers hands-on science activities incorporating traditional Aboriginal tool making and ancient techniques for bush survival and sustainability linked to practical experiments in forensic chemistry, such as fingerprinting and chemical analysis of samples. The Nyoongar boodja "Synergies of Meaning Research Project" used Koodjal Jinnung to generate a conjoint timeline of the history of Nyoongar boodja. The geology and climate history of the land was synthesised into a story and laid alongside traditional knowledge and stories; the resonances were astonishing and are presented in an academic article (Robertson, Nannup, Stasiuk, \& Hopper, 2016) and a book by the same authors intended for general readership (Robertson, Barrow et al., 2017). Lottery West funded a film of this work, titled Walking Together Belonging to Country (Stasiuk, Robertson, Naanup, \& Hopper, 2015).

The "Western Australian Aboriginal Journey Ways Project" was undertaken by Robertson and Nannup (2016, 2017, 2018). This project collated Aboriginal use of routes that are now part of the main roads network across the state. Consultations with local Elders enabled the interpretation of some stories as instructive metaphors for climate-induced changes to the local ecology. For example, a story from around Gutharraguda (Shark Bay) concerns the transformation of a freshwater drinking goanna into a cutaneous water-gathering thorny devil, this transformation being a punishment for drinking all the fresh water and urinating in it so it became undrinkable water. This story is a clear indication of the desertification of the area and is reflected in human occupation of the area. People occupied Gutharraguda at least 30,000 years ago, but between 18,000 and 7000 years ago there is no evidence of occupation, a time of low sea levels and intense desertification, yet the story survived. By 7000 years ago, the sea level had risen, defining the two arms and creating the super-salinated inner bay.

The "Moort (Nyoongar family system) Project" gathered a multidisciplinary team of Elders, a family practitioner, a Nyoongar epidemiologist and an evolutionary biologist to construct an in-depth portrait of the moort, the traditional Nyoongar family system. This traced the development of seven key values that underpin community and family life and inform the operational dynamics, which vary in response to local conditions. Researchers Robertson, Nannup, Coall, McAullay, and Nannup (in press) found that in difficult times during drought and European occupation, these values are held above individual desires or local expediencies. In these and other like projects a number of mechanisms by which Nyoongar people have adapted to climate change have been 
identified. These adaptations have been published in academic papers, books for general readership and in a film; however, they have not until now been collated for publication in a specific climate change journal.

\section{Climate change and its impact on the ecology of Nyoongar boodja}

Research on aridity during the Pleistocene by Munyikwa (2005) indicates that when people first arrived in Nyoongar boodja the climate was approximately $4^{\circ} \mathrm{C}$ cooler than today, and wetter because there was less evaporation. For example, there were grasslands with surface water, permanent lakes and river systems, and mega-fauna. At the time of early occupation, sea levels were some $40-60 \mathrm{~m}$ below current levels.

There is a consensus in the literature about the impact of the Last Glacial Maximum (LGM) in Australia. Cane (2013) and Ward, Larcombe, and Veth (2015) indicate it began around 35,000 years ago with a gradual reduction in temperature. By 25,000 years ago there was severe glaciation with temperatures $6-10^{\circ} \mathrm{C}$ below current temperatures. By 22,000 years ago, the glaciers were thickest, with ice sheets covering most continents. Sea levels were at their lowest, dropping to approximately 150-400 m below current levels. There were no glaciers in WA; rather, a great drought, the worst of which was between 25,000 and 15,000 years ago during which time most of the Australian megafauna became extinct. Archaeologists Williams, Ulm, Cook, Langley, and Collard (2013) suggest that the Aboriginal population numbers fell by around $60 \%$ after having stable sustained growth.

From 15,000 years ago, the climate warmed, the glaciers melted and rain systems returned. There are notable differences in the warming process between the northern and southern hemispheres. For example, the Younger Dryas, an intensely cold phase beteen 12,900 years and 11,700 years, was thought to have been a global phenomenon. Burrows (2012) suggests the southern hemisphere did not cool during this period; rather, temperatures were actually 2 degrees warmer than today.

There is a consensus too in the literature about the impact of warming in Australia: the thermal maximum was reached approximately 8000 years ago with sea levels some $2.5-4 \mathrm{~m}$ higher than the average for the 20th century. Over the next few thousand years, the sea level dropped to its current level and the climate became warm and dry, with oscillations between droughts and flooding rains.

\section{Resilience factors during the great drought}

Resilience, in this context, refers to the capacity of a community to maintain its functioning during periods of significant ecological challenge. Previously mentioned research on the history of Nyoongar people indicates there were three resilience factors through which Nyoongar people responded to climate change. First, and most importantly, underpinning other technological mechanisms, was their social organisation, a family and community structure that embedded cooperation rather than competition. This enabled them to reduce and increase population size without conflict. Second, manipulation of the environment enabled them to enhance water catchments to stimulate resource generation and to corral animals. Third, resource and idea sharing with other groups, including artefacts and genes across vast distances, facilitated survival. 


\section{Family and community structure}

Evolutionary biologist Emlen (1995) identified two types of families evolving differently in response to local conditions. First, those arriving in stable ecologies fill the area, and when near carrying capacity is reached, the population settles at a sustainable level. Second, those arriving in severely fluctuating ecologies tend to rapidly fill the area and use up all the resources until there is a crash in numbers, with the residual population moving on and recovering. It would seem that from when they arrived and for the first 15,000 years of occupation, Nyoongar people enjoyed a well-resourced and stable ecology. This enabled people to disperse across the area and establish a sustainable population. There is a consensus in the archaeological literature and Nyoongar stories that what emerged was a hunter-gatherer economy. Possibly then and certainly later, the population also used some farming tecniques, particularly firestick and aqua farming (David, Barker, \& McNiven, 2006). Although it is difficult to date such activities, recent finds associated with their use include grinding stones that were made at a site occupied 65,000 years ago in Madjedbebe in the Northern Territory (Clarkson, Jacobs, \& Pardoe, 2017).

It was probably during the first 15,000 years of occupation that Nyoongar people established their 14 nations, sharing the same spiritual beliefs, moral codes, clan structures and language root but each uniquely detailed as they responded to local conditions (Robertson, Stasiuk, Nannup, \& Hopper, 2016). Each clan had a kourliny bidi, known more recently as a run, a distance of approximately $250 \mathrm{~km}$, which they moved through during the six seasons of each year. There were points of gathering within and between nations for trade, for marriage, for ceremony and for law. There were strict rules about moving outside of the run, which prevented conflict. There was intermarriage between clans and nations, which also decreased the chance of conflict. Nyoongar people were linked into trade routes that extended across the country (Kerwin, 2006). Thus, as the LGM began to have an impact, the Nyoongar people already had in place mechanisms for the management of people, for rapid communication between groups, and for the transfer of ideas about how to survive the increasing cold and dryness.

As discussed earlier, the LGM was a gradually encroaching and eventually devastating event. Water systems began to dry up, areas that were once lush became deserts, and some species, especially mega-fauna, became extinct. Population reduction, both in numbers and stature, are normal responses to such devastating ecological changes and can occur through fighting over resources and through starvation. Research on moort (the Nyoongar family system) by Robertson, et al. (in press) indicates this did not happen within the Nyoongar community because of two key family values: danjoo maam yok winni rak kardip (mutual gender respect and sharing) and dalbarbak koolangarra (the honouring of children and childhood). Danjoo maam yok winni rak kardip concerns the classic hunter-gatherer division of labour in which men hunt animals and women gather seeds, nuts and small animals. This division is predicated on sharing; at the end of the day food is brought back to the narla kala (our campfire) to share. Thus, there are two complementary skill and knowledge sets, which are extended into men's business (land and clan boundary) and women's business (marriage, fertility and child raising).

Danjoo maam yok winni rak kardip meant that women were able to determine the timing and numbers of children they bore. Population numbers could be reduced by fewer and later marriages, and it is likely that late weaning was used to delay conception of second and subsequent children. This was not all that late weaning achieved:

Late weaning also "adapts" the child's growth to the level of available protein-where maternal nutrition is compromised, exclusively breastfed infants are less likely to be stunted or underweight but not significantly so (Kramer \& Kakuma, 2012). This may indicate that poor 
nutrition in one generation leads to smaller offspring in the next. In a modern context this has negative connotations, being referred to as stunting and wasting, but from an evolutionary perspective it can be understood as developmental plasticity, an adaptation to diminishing resource availability. This epigenetic effect associated with late weaning enables populations to adapt, over generations, to reductions and changes in nutrition associated with gradual climate change. The reduction in stature over generations in response to maternal malnutrition and stress was noted in the descendants of famine survivors and is theorised as "intergenerational phenotypic inertia", which limits changes in growth rate in response to short-term ecologic fluctuations, and responds to longer term nutritional trends in the local ecology (Kuzawa, 2005). (Robertson, Coall, McAullay, \& Nannup, 2019, p. 5)

Emlen's (1995) theory on the evolution of family structure in response to ecology indicates those living in unsettled ecologies had more children but higher maternal, infant and child mortality. In the United Kingdom and other North European nations, where women were mostly unable to take charge of their fertility, this pattern continued until the beginning of the 20th century (Razzell \& Spence, 2005; Woods, 2000). Nyoongar people almost certainly had fewer children and much lower maternal, infant and child mortality. This enabled them to dalbarbak koolangarra (honour children and childhood).

A review of traditional Nyoongar stories conducted for the Nyoongar Boodja Synergies Project indicated two types of stories about cold times. There are epic stories about the creation of Nyoongar boodja during the Nyetting (the cold time) and stories about what seem to be real people struggling with nyidiny (cold). These are probably stories from the great drought, as they concern life in very tough conditions. They include stories about how to keep fire alive; for example, in the story of Kwenda, Djilidjili and Wata (Bandicoot, Sparrowhawk and Pigeon) fire is the central issue. If Nyoongars had no fire, they had to eat their meat raw, and when the cold waters came "they would long for the sun to shine down to dry the land and warm them". This instructive story tells listeners which wood burns well and gives good ash, and that some wood, such as banksia, could be made into firesticks and carried around for a long time so they would always have fire. ${ }^{1}$ Other stories concern a dilemma all social groups face: What is more important? Individual desires or community needs? Nyoongar stories indicate that the law prevails and the individual who does not meet community values is punished with exile or death. These stories suggest that the evolutionary imperative to balance the relationship between population numbers in severe cold and drought was, for Aboriginal people, expressed culturally in the sublimation of individualism. The pay-off for this was that lineages (bloodlines), community and culture survived (Robertson et al., in press).

\section{Manipulation of the environment to enhance water catchment}

During the LGM, much of the planet's fresh water was locked in glaciers, and Nyoongars had to adapt to desert conditions. In the absence of rain, Nyoongar people had to get water out of the air. The thorny devil does not drink water; rather, it acts as a condenser and channels moisture from the air or buried sand between the scales towards its mouth (Comanns, Withers, Esser, \& Baumgartner, 2017). Using the same principle to create new or extend existing gnamma (rock holes), Nyoongar people:

... would find a fault in the rock and build a fire on it. When the rock was really hot they would throw water on it to cool it, suddenly the rock would crack and they lifted pieces out. They kept doing this until the hole was deep enough to hold a good amount of water. Gnamma are not reliant on rain, at night the Wheatbelt temperature drops, the granite cools and water in the atmosphere condenses, this collects in the gnamma holes. Even in the hottest driest weather the gnamma hole have fresh water in the morning. Sometimes they put a lid on it to make sure 
animals didn't fall in and drown. Every so often they would clean the gnamma hole by dragging a tea tree branch through it. (Davis \& Davis, 2016, p. 9)

Nyoongar people used the same principle to construct remarkable farms:

At Walunga (now a national park) there is evidence of an extensive Nyoongar campground. Up the hill from the river is a farm, which uses the same mechanism as the gnamma in both a large and small scale. What looks like a messy rock scatter is actually a giant rockery, the stones have been placed to form terraces to catch water. Likewise, pulling aside a quantity of litter reveals a "plant pot". The circle of stones is positioned so that any condensation is directed to the centre where, probably, a tuber was planted. (Robertson, Nannup et al., 2019, p. 21)

The eastern Wheatbelt is dotted with ancient rocky outcrops; during the great drought and other dry periods, these rocks are beacons for life:

On travelling east from Perth on the Great Eastern highway there is a point where Nyoongar names for places stop being that of totem animals and become associated with rocks. From Bungella onwards granite outcrops and rocks become more significant in the naming of places. The rocks remain of great significance to the Njaki Njaki people. In times when the area was dry, rocks meant water. Even when there is no rain, water in the atmosphere condenses on the rock at night. This creates run off which waters plants and attracts animals. (Robertson \& Nannup, 2018, p. 40)

Remarkably, saltwater is also a source of freshwater, some salt lakes being home to freshwater springs. The top millimetres of saltwater, whether lake or ocean, is fresh:

On the shores of the salt lake are small channels, these are the marks of freshwater runoff. Dig down at the base of one of these channels and there may be a little reservoir of fresh water. If you are truly desperate there is another way, by collecting the top few millimetres off the salt lake. Just as at the ocean those top few centimetres are fresh water and with skill and patience you can harvest this tiny amount of water, which can keep you alive, (Davis \& Davis, 2016, p. 10)

The authors speculate that fish traps, typically the arrangement of rocks to catch fish on an ebbing tide, were used throughout the Nyoongar occupation; however, sea level rises have destroyed evidence of all but the most recent. There are fish traps around what is now Albany and at the mouths of other rivers, but it is not known how old they are.

\section{Fire management and fire farming}

Fire has always been an issue in Australia:

Aboriginal people, like Australians today, had to come to terms with fire. A study of charcoal sediment indicated no distinct change in the frequency of biomass burning in Australia from approximately 50,000 years ago to today (Mooney et al., 2011). Either a system of controlled burning was established, or nature was left to take its course (Robertson, Nannup, Stasiuk, \& Hopper, 2017, p. 42)

It is possible that firestick farming developed because of observations made by early Nyoongar people and in response to drier conditions, as is thought by Wheatbelt Elders living in the Wyalkatchem area: 
Without controlled burning there would have been catastrophic fires, with vast fronts that destroy everything. Plants like acacia and mulga sprout after stress such as a fire and the old Nyoongars would have noticed that. Soon they were using controlled burning to farm. The idea was to burn sections of land at different times, when one area was burnt it would sprout and the animals would come in to graze, they could take what animals they needed. There are five local words about fire stick farming:

- Kappi (ground ready for burning);

- Bokyt (ground clothed with vegetation which has not been burnt);

- Kundyl (young grass springing back after the country have been burned);

- Narrik (land where the vegetation is abundant, dry and ready for burning; and

- Nappal (burned ground). ${ }^{2}$ (Davis \& Davis, 2016, p .10)

The language here is about kaarl ngara (fire in relation to land) and reflects the mosaic or four-field cycle of burning off that ensured one local patch of land always had new grass and was regenerating trees to attract kangaroos and other animals, which were sustainably farmed (Gammage, 2011; Hallam, 1975). The benefits of this kind of fire management are threefold: animal habitats are preserved, there is no catastrophic devastation in which seeds and soil are incinerated, and new growth in recently burned areas attracts animals needing to feed (Hallam, 1975; Johnson, 2006).

\section{Sharing of ideas, artefacts and genes across vast distances}

One of the problems associated with a much-reduced, interrelated population, particularly during the great drought, concerned the maintenance of a healthy gene pool. A key value identified in the moort research is moiety, which was and remains widespread among Aboriginal people. At its simplest, a moiety system is the designation of each newborn into one of 4,8 or 16 groups depending on their bloodline. Each group is represented by a totem, and people cannot marry a person of the same totem. Moiety is a way in which a relatively small group of interrelated people tied to a place can protect the gene pool over many generations. This is supported by "genetic circulation" on a wider scale, such as the transfer of people along trade routes. Nyoongar boodja is at the end of a trade route where a different mechanism was in place:

Every second djoowak (15 years) a group of nubile Nyoongar girls were selected to travel east to the edge of Nyoongar territory and were passed over to the Wongai people. This is usually signalled by a great number of shooting stars. All the girls born in that year are sent to live and marry beyond their tribal grounds. This movement of people between tribes was consistent across the country and ensured the health of the gene pool was constantly maintained. (Elder Noel Nannup, 2014, as quoted in Robertson, Nannup, Coall, McAullay, \& Nannup, in press)

Veth (1995) developed a model to explain the history of human occupation of Australia for the previous 40,000 years. This divided Australia into three biogeographical concepts: refuges, barriers and corridors. Refuges were comprised of uplands and riverine and gorge networks that provided reliable networks of water during climatic oscillations. Barriers were large sand ridge deserts, and corridors were large tracts of sandy and stony lowlands that, arguably, were habitable only during climatically favourable periods (Veth, 1995). The refuges in WA were Nyoongar boodja, the Pilbara tablelands and the Kimberley plateau. During the great drought, populations clustered in refuges and visited other refuges when the climate permitted (Veth, 1995).

Making a visit from Nyoongar boodja to another refuge during the great drought would have been a daunting journey $-500 \mathrm{~km}$ by the most direct route today. The thorny devil story from Gutharraguda (Shark Bay World Heritage Area; https:// www.sharkbay.org/culturehistory/aboriginal-heritage/) would have been a warning not to take the coast route. Two other 
routes were feasible; one of these was a route that tracked north-south on the eastern side of Western Australia:

... following a chain of saltlakes, in which there are also freshwater springs, from Kepacurl (Esperance) to Wiluna then to Halls Creek in the Kimberley via Yiwarra Kuju (Davenport \& Johnson, 1998). This was a journey way used by the Martu people of central Western Australia who have cared for this route, and the fifty or so watering places along the way, for millennia. (Robertson, Nannup et al., 2019, p. 34)

This saltlakes route follows ancient cross-country trading routes between the northern and southern coasts; for example, engraved pearl shells from Murujuga (Burrup Peninsula) made their way to the Great Australian Bight. Goods passed on routes between Meekatharra and Yincular (Eucla) included ochre, shells, certain rocks and pituri (bush tobacco; Kerwin, 2006).

There was also a western inland route between Talanup (Augusta) and Yirramagurdu (Roebourne). Use of this route is described in an ancient account of a boranga boongorang (great shaking) that caused saltwater inundation of freshwater resources and a community's response to the sudden reduction in resources this incurred. The Elder who carries this story described its significance:

The great shaking happened at Black Point. Close by is Yoondanup, a freshwater lake which originally formed around a spring. Many people were camped there. When the great shaking came the spring broke and flooded the land. The people who camped there moved north; many people up north believe this is where they came from. Since then, people have been walking that route northwards, some go north to Wiluna to see family. Many of us are connected up as far as Yirramagurdu (Roebourne). (Wayne Webb, as quoted in Robertson, Nannup et al., 2019, p. 28)

\section{Resilience factors during the glacial}

In the 7000 years between 15,000 years ago, the edge of the great drought, and the Thermal Maximum 8000 years ago, temperatures rose from $6-10^{\circ} \mathrm{C}$ below to $5-8^{\circ} \mathrm{C}$ above current temperatures (Mclnerney \& Wing, 2011). The sea rose from up to $400 \mathrm{~m}$ below to 2.5-4 $\mathrm{m}$ higher than the average for the 20th century (Monroe, 2011). During the post-glacial rebound, Australia moved from a cold and dry climate to the warm and dry climate we experience today. The hill that is now Wadjemup (Rottnest Island) and the ridge that is now Yondocht Minditj (Garden Island) were surrounded by water. The sea flooded up Derbyl Yerrigan (Swan River), and the river system took on its current estuarine qualities.

\section{Conscious cooperation with nature and with natural processes}

A key value of Nyoongar life is kallip, the amassing and preservation of knowledge about people, their environment and its systems. The primary reason for kallip is cooperation-to live sustainably within nature's bounty. Everything is understood in terms of its kinesis: the movement through its own life cycle and the movement created by its relationship with others. This knowledge is both a practical knowledge and a spiritual knowledge. As a practical knowledge, it informs when various activities such as hunting, fishing and burning should be undertaken. As a spiritual knowledge, it holds the story of bigger natural cycles, such as the annual rain cycles and the longer climatic cycles (Robertson et al., in press. 
Changes incurred by the warming are documented in many Nyoongar stories. For example, In When the Sea Levels Rose (Nannup, 2006) the last story of the creation trilogy, special roles are allocated to the spirits of nginyarn (echidna) and kaarda (goanna) to care for the Spirit Children and the spirits of those who were buried in the land that was to be flooded. They convince mamang (whale) and kwilana (dolphin) to bring the spirits to rivers and beaches with freshwater springs and release them so they can reach land. The Crocodile and the Dingo story told by Trevor Walley concerns the arrival of the saltwater crocodile (a creature from northern Australia not found in the waters of the South West) who thrashed around in the sea as it rose. This noise was heard by the Waakarl (rainbow serpent) who instructed the djiralji (a little gecko), a keeper of the cave near what is now Fremantle, to twist the crocodile into pieces. Big waves of saltwater were coming up the river, so djiralji got the tail and put it across the entrance of the Swan River and called it warra nurt (bad tail). He got dwert (dingo) to sit on top of the hill to watch him, to see he does not get his tail back.

Likewise in Kalingiri (Albany) before the sea level rose, the Kalgan and King rivers ran down off the scarp, creating a deep scar in what is now undersea landscape. At that time the Nyoongar people lived on the old coastline where it was flat. The Two Snakes story told by Carol Pettersen tells not only of the harbour forming but also of the hills behind Albany becoming integrated into Nyoongar people's lives as they moved there to be safe from the rising waters. The story concerns two snakes who were brothers who have an argument and a lengthy fight; their rolling around created the harbour and the islands. Finally, in retreat they created the rivers and their blood became patches of red ochre.

\section{Cooperation with others}

The speed and intensity of change, particularly when there was sudden inundation of land or freshwater sources with saltwater, would have led to population shifts, straining relationships. It is likely that at times Nyoongar people had internal boundary issues with their neighbours, as exemplified in the great shaking account. They may have continued to do so during the next 8000 years as the climate oscillated between warmer and wetter, and cooler and drier cycles shrinking and expanding desert areas. For example, the area now occupied by the Njaki Njaki at the eastern edge of Nyoongar boodja at times resembled the land occupied by the desert people and at other times resembled land typically occupied by Nyoongar people. It is not surprising that today there is disagreement about where the western border of Njaki Njaki land is. Despite these localised issues, there is no evidence of systemic warfare.

This lack of conflict was due to their culturally embedded capacity for cooperation with the land and its cycles and with each other. It would seem that when there were problems, people got together and yarned (talked) until a solution was reached. There are meeting places across Nyoongar boodja-some are internal borders between Nyoongar nations that provide a venue for internal cooperation. This level of cooperation was extended to other groups such as the Wongai people and the Yamatji people on the eastern borders, with whom they had intermarried for many generations.

\section{Managing the threat of epidemic disease}

When Europeans began arriving in Nyoongar boodja in 1826 they brought epidemic disease with them, and they brought some immunity. As previously mentioned, the predominantly British and Irish men who settled on Nyoongar boodja were mostly the very poorest of people: 
Despite their lowly origins they were tenacious survivors; their antecedents had survived repeated epidemics of smallpox, plague, influenza and other zoonotic diseases incurred through farming after the Last Glacial Maximum in Europe (Scott 2017). In their childhood they survived the epidemics of measles, scarlet fever and diphtheria and persistent extreme poverty that routinely killed a third to one half of all their siblings (Razzell \& Spence, 2005). They survived the pressures of the not unusual death or loss of a parent or parents (Honeyman \& Goose, 2013). Those from Ireland had also survived the famines of 1845 and 1852 that killed between a fifth and a quarter of the population (Ross, 2002). As orphans, workhouse inmates, soldiers and convicts and as travellers in the stinking holds of ships they survived the diseases of poverty and overcrowding such as tuberculosis, typhus and cholera. (Robertson et al., in press)

This group, economically poor and immunologically rich, impregnated Nyoongar women, usually by rape. The key value dalbarbak koolangarra (the honouring of children and childhood) meant that children were never blamed for the circumstances of conception, and they were raised within the community. The first generation of this cohort inherited some immunological richness from their fathers. They married within the community and girls went on to breastfeed their children, conferring immunity in the next generation. Subsequent generations developed a level of immunity to introduced diseases. Just as the key family value of danjoo maam yok winni rak kardip (mutual gender respect and sharing) supported gradual adaptation to climate change, dalbarbak koolangarra (the honouring of children and childhood) supported the development of immunity to introduced diseases. These and other values are upheld above individual desires or local expediencies.

\section{Discussion}

The research discussed in this article shares ancient technologies that are now being imitated in a number of ways. For example, hydropanels, which are said to draw water out of thin air, use the gnamma technology. Hydropanels use solar power to collect water vapour from the air, which is then mineralised and piped into a water tank ready for consumption. They are used in remote desert communities where water supply during the summer months can be compromised. Some traditional technologies are not being used, arguably with catastrophic consequences. Recent massive fatal fires, some in Nyoongar boodja, indicate a continuing failure to use Aboriginal methods to manage the fire hazards inherent in the Australian ecology. Despite repeated and ongoing offers by Aboriginal people to work with fire services, their voices about fire management struggle to be heard, let alone incorporated widely into practice:

There's been a continuation of knowledge that's been passed from one person to another, and we can go right back to so many generations of our old people. What I would like to say is it's time for government bodies, those dealing with fire departments, and other departments to listen to us as Noongar people - we have so much to say, and yet we're not given an opportunity to speak... We must take care of our land, otherwise those beautiful creatures won't be with us much longer. We're already in a state of devastation I believe. And on top of that there is a need to heal our land...So I say, for us as a people, Australia - unite with us; Western Australia - unite with us. Talk to our people...We have so much to give...There is still more to come. (Elder Elizabeth Hayden, 2020) ${ }^{3}$

Some proscribed burning takes place, but it is not undertaken in an Aboriginal manner; consequently, the burning off is creating a great deal of smoke rather than cool. This is because burning off is done according to a four-season European calendar rather than the six-season Nyoongar calendar. 
Survival in a future affected by significant climate change will be assisted by technological innovations using concepts devised from observation of natural phenomena made by Aboriginal people millennia ago. It is, however, the values we espouse that will see us through. Nyoongar people defined their values very early in the occupation of their boodja and held on to them most strongly when life was toughest. It was those values that returned benefits in the long term, ensuring the survival of Nyoongar people and culture. As COVID-19 evolved as a pandemic, the WA government adopted a number of first step measures that, although not described as such at the time, were based on the value of protecting the most vulnerable in the population. These included rounding up the homeless and placing them in hotels, assisting Aboriginal people to return home and then creating regional travel bans, and limiting daily sales of alcohol.

Operating by values often brings about unforeseen positive advantages, as it did for Nyoongar people. Placing homeless people in hotels was done before it was realised COVID-19 disproportionately impacted the poor. Placing the homeless in hotels where they could self-isolate meant they were protected, less likely to unknowingly transmit the disease, and less likely to be in hospital. It also meant that hotels accepting these guests were able to continue operating.

The creation of travel bans during the pandemic was not unusual; the WA government also closed access to remote communities, particularly in the Western Desert, the Pilbara and the Kimberley. Relative to Perth, these areas have larger populations of Aboriginal people, many living in remote communities. Older Aboriginal people have poor health, a legacy of previous government policies. They are children of people who survived the Killing Time ${ }^{4}$ (Perkins \& Langton, 2010) and were themselves slaves or the children of slaves on stations and farms, and during that time suffered famine and subfamine conditions (Smith, 2000). Even after the 1967 referendum that eventually led to equal wages and access to child benefits and maternity allowance and the freedom to marry, there were problems. Many people were trucked off stations and dumped at reserves that had no amenities, such as running water and toilets. Life on these reserves was very difficult and has had implications for their descendants' health (Robertson, Coall, McAullay, \& Nannup, 2019). Consequently, many grew up with wet cough and other chronic ailments that would severely impact their capacity to survive COVID-19. Closing roads protected another very vulnerable group who remain among the poorest in WA (Robertson, Coall et al., 2019).

Limiting the amount of alcohol that could be purchased in one day to one carton of beer and three bottles of wine or equivalent was another mechanism by which Aboriginal communities were protected. Many communities, by choice, were already alcohol free or had introduced liquor restrictions. Preventing sly grogging (the illicit introduction of alcohol) is an ongoing challenge. Limiting daily sales of alcohol meant sly grogging was no longer financially viable. Local police reported a $40 \%$ reduction in alcohol-fuelled violence that did not involve family members. This was more than twice the percentage fall in Perth in the same period. (March 1-April 5, 2020). Conversations with people in communities in the Kimberley indicate the lockdown has seen a return to a more traditional lifestyle and to traditional ways of getting food, with a subsequent improvement in health. As at June 11, 2020, WA recorded 602 cases of COVID-19, of which 522 were brought into the state from interstate, overseas or cruise ships, and 64 were transmitted from those sources. There were only 9 deaths in a population of 2.72 million.

\section{Conclusion}

This review of Nyoongar history shows that Nyoongar people were continuously on their boodja for at least 48,000 years, and that during that time they experienced significant climate change and massive fluctuations in sea levels. They responded to these challenges with technological 
solutions. Nyoongar people, possibly as a result of the beneficence of their early environment, had developed a value-based, highly cooperative society. As the environment became significantly more challenging, and with no way of predicting the severity or length of the climate change that confronted them, they acted as they had always done-they cooperated with nature, followed their values, and stored what they learnt from their experiences in stories. Consequently, when the LGM presented them with a 10,000-year drought, they drew water out of the air, farmed and fished between the stones, and the population diminished its size and stature in line with available resources. The alternative to such practices is persistent looting of resources. When resources are diminished there is fighting, and when resources are gone there is famine.

When confronted by rapacious Europeans, Nyoongar people followed their values and were able to diffuse immunity to introduced diseases so that when they were trapped in western enclosures, missions, orphanages and reserves, they survived. When faced with a pandemic that most adversely affects the poorest and most vulnerable people, a society can introduce policy responses designed to protect them first, or it can ignore them.

Survival in a future affected by significant climate change will be assisted by technological innovations. Some innovations will use concepts devised from the observation of natural phenomena made by Aboriginal people millennia ago. It is, however, the values we espouse that will make survival worth it. Nyoongar people defined their values very early in the occupation of their boodja and held on to them most strongly when life was toughest. It was those values that returned benefits in the long term, ensuring the survival of Nyoongar people and culture. 


\section{References}

Bates, D. (1992). Aboriginal Perth and Bibbulmun biographies and legends (P. J. Bridge, Ed.). Hesperian Press.

Burrows, T. (2012). The Younger Dryas: Relevant in the Australian region? Quaternary International, 253, 47-54. doi:10.1016/j.quaint.2012.01.003

Cane, S. (2013). First footprints: The epic story of the first Australians. Sydney, Australia: Allen \& Unwin.

Clarkson, C., Jacobs, Z., \& Pardoe, C. (2017). Human occupation of northern Australia, Nature, 547(7663), 306-310.

Comanns, P., Withers P.,C., Esser, F.,J., Baumgartner, W. (2016) Cutaneous water collection by a moisture-harvesting lizard, the thorny devil (Moloch horridus). Journal of Experimental Biology, 219, 3473-3479. doi:10.1242/jeb.148791.

David, B., Barker, B., \& McNiven, I. J. (Eds.). (2001). The social archaeology of Australian Indigenous societies. Canberra, Australia: Aboriginal Studies Press.

Davis, R., \& Davis, K. (2016). Wyalkathchem The Nyoongar story. Perth, Australia: Edith Cowan University.

Emlen, S. (1995). An evolutionary theory of the family. Proceedings of the National Academy of Sciences of the United States of America, 92(18), 8092-8092.

Gammage, B. (2011). Fire in 1788: The closest ally. Australian Historical Studies, 42, 277-288.

Hallam, S. J. (1975). Fire and hearth: A study of Aboriginal usage and European usurpation in south-western Australia. Canberra, Australia: Australian Institute of Aboriginal Studies.

Hesp, P., Murray-Wallace, C., \& Dortch, C. E. (1999). Aboriginal occupation of Rottnest Island, Western Australia. Australian Archaeology, 49, 7-14.

Honeyman, K., \& Goose, N. (Eds.). (2013). Childhood and child labour in industrial England: Diversity and Agency 1750-1914. Ashgate, UK: Routledge.

Johnson, C. (2006). Australia's mammal extinctions: A 50,000 year history. Melbourne, Australia: Cambridge University Press.

Kemmis, S., \& McTaggart, R. (2005). Participatory action research: Communicative action and the public sphere. In N. K. Denzin \& Y. S. Lincoln (Eds.), The Sage handbook of qualitative research (3rd ed., pp. 559-603). Thousand Oaks, CA: Sage.

Kerwin, D. W. (2006). Aboriginal Dreaming tracks or trading paths: The common ways. (Unpublished PhD thesis). Griffith University, Australia.

Kramer, M. S., \& Kakuma, R. (2012). Optimal duration of exclusive breastfeeding. Cochrane Database of Systematic Reviews, 2012(8) CD003517. doi:10.1002/14651858.CD003517.pub2

Kuzawa, C. W. (2005). Foetal origins of developmental plasticity: Are foetal cues reliable predictors of future nutritional environments? American Journal of Human Biology, 17(1), 5-21. doi:10.1002/ajhb.

Mclnerney, F. A., Wing, S. (2011). A perturbation of carbon cycle, climate and biosphere with implications for the future. Annual Review of Earth and Planetary Sciences, 39, 489-516.

MacNaughton, G. (2001). Action research. In G. MacNaughton, S. A. Rolfe \& I. Siraj-Blatchford (Eds.), Doing early childhood research: International perspectives on theory and practice (pp. 208223). Sydney, Australia: Allen \& Unwin. 
Monroe, M. H. (2011), Australia: The land where time began. http://austhrutime.com

Mooney, S. D., Harrison, S. P., Bartlein, P. J., Daniau A. L., Stevenson, J., Brownlie, K. C., ... Mckenzie, G. M. (2011). Late Quaternary fire regimes of Australasia. Quaternary Science Reviews, 30, 28-46.

Munyikwa, K. (2005). Synchrony of Southern Hemisphere Late Pleistocene arid episodes: A review of luminescence chronologies from arid aeolian landscapes south of the Equator. Quaternary Science Reviews, 24, 2555-2583.

Nannup, N. (2006). When the sea level rose. Perth, Australia: Swan Catchment Council.

O'Connell, J. F., \& Allen, J. (2012). The restaurant at the at the end of the universe. Modelling the colonisation of Sahul. Australian Archeology, 75, 5-17.

Perkins, R., \& Langton, M. (2010). First Australians. Melbourne, Australia: Miegunyah Press.

Razzell, P., \& Spence, C. (2005). Social capital and the history of mortality in Britain. International Journal of Epidemiology, 34(2), 477-478. doi:10.1093/ije/dyi035

Roberts, R. G., Spooner, N. A., Jones, R., Cane, S., Olley, J. M., Murray, A. S., \& Head, M. J. (1996). Preliminary luminescence dates for archaeological sediments of the Nullarbor Plain, South Australia. Australian Archaeology, 42(1), 7-16.

Robertson, F., \& Nannup, N. (2016). Nyoongar Bidi (Research report for the Western Australian Aboriginal Journey Ways). Perth, Australia: Main Roads Western Australia.

Robertson, F., \& Nannup, N. (2017). Inland routes, desert routes and long way long time (Research report for the Western Australian Aboriginal Journey Ways). Perth, Australia: Main Roads Western Australia.

Robertson, F., \& Nannup, N. (2018). The Kimberley (Research report for the Western Australian Aboriginal Journey Ways). Perth, Australia: Main Roads Western Australia.

Robertson, F., Nannup, N., Coall, D. McAullay, D., \& Nannup, A. (in press). Moort; A celebration of a traditional and contemporary Aboriginal family system. Batchelor, Australia: Batchelor Press.

Robertson, F., Barrow, J., Wajrak, M., Nannup, N., Bishop, C., \& Nannup, A. (2017). Participatory action and dual lens research. Qualitative Research Journal, 17(4), 283-293.

https://doi.org/10.1108/QRJ-12-2016-0075

Robertson, F., Nannup, N., Stasiuk, G., \& Hopper, S. (2017) Nyoongar Boodja - Koomba Bardip Kooratan [Nyoongar Land - Long Story Short]. Batchelor, Australia: Batchelor Press.

Robertson, F., Stasiuk, G., Nannup, N., \& Hopper, S. D. (2016), Ngalak koora koora djinang (Looking back together). A Nyoongar and scientific collaborative history of ancient Nyoongar boodja. Australian Aboriginal Studies, 1, 40-54.

Robertson, F., Nannup, N., \& Barrow, J. (2019). Great journeys undertaken by Aboriginal people in ancient times in Western Australia. Batchelor, Australia: Batchelor Press.

Robertson, F., Coall, D. McAullay, D., \& Nannup, A. (2019). Intergenerational influences of hunger and community violence on the Aboriginal people of Western Australia: A review. International Journal of Critical Indigenous Studies, 12(2), 34-46.

Ross, D. (2002). Ireland: History of a nation. New Lanark, UK: Geddes \& Grosset.

Smith, P. A. (2000). Station camps: Legislation, labour relations and rations on pastoral leases in the Kimberley region, Western Australia. Aboriginal History, 24, 75-97. 
Stasiuk, G., Robertson, F., Nannup, N., \& Hopper, S. (2015). Synergies: Walking togetherBelonging to Country [Djena Koorliny DanjooBoodjar-ang].

https://www.youtube.com/watch?v=aeGqTpLDYjQ\&feature=youtu. be

Taylor, S. (1981). Who were the convicts? A statistical analysis of the convicts arriving in Western Australia in 1850/51, 1861/62, and 1866/68. Studies in Western Australian History, 4, 19-45.

Turney, C. S. M., Bird, M. I., \& Roberts, R. G. (2001). Elemental 18C at Allan's Cave, Nullarbor Plain, Australia: Assessing post-depositional disturbance and reconstructing past environments. Quaternary Science Reviews, 16, 779-784.

Turney, C., Bird, M., Fitfield, K., Roberts, R., Smith, M., Dortch, C., ... CresswelL, R. (2001). Early Human Occupation. Quaternary Science Reviews, 55, 3-13.

Veth, P. (1995). Islands in the Interior: A model for the colonisation of Australia's arid zone archeaeology. Oceania, 24, 81-92.

Ward, I., Larcombe, P., \& Veth, P. (2015). A new model for coastal resource productivity and sealevel change: The role of physical sedimentary processes in assessing the archaeological potential of submerged landscapes from the Northwest Australian Continental Shelf. Geoarchaeology, 30, 19-31.

Williams, A. N., Ulm, S., Cook, A. R., Langley, M. C., \& Collard, M. (2013). Human refugia in Australia during the Last Glacial Maximum and Terminal Pleistocene: A geospatial analysis of the 25-12 ka Australian archaeological record. Journal of Archaeological Science, 40, 4612-4625.

Woods, R. (2000). The demography of Victorian England and Wales. Cambridge University Press. https://ourworldindata.org/life-expectancy/

\footnotetext{
${ }^{1}$ These stories were collected by Daisy Bates before 1907 (Bates, 1992).

2 These words are also found in "Recording Traditional Knowledge, Our Country...Our Stories...Our People", 2008, Sandra Harben and the Murdoch University Project Team for Avon Basin Noongar Heritage and Cultural Significance of Natural Resources.

${ }^{3}$ Selected quotes from the Knowing Fire, Caring for Country Symposium, April 30, 2020, Western Australia.

4 The Kimberley Aboriginal term for the period 1890-1926 when the government implemented a "pacification" policy in the east Kimberley. During that time a quarter of the Western Australia police force was deployed in the Kimberley where only $1 \%$ of the white population dwelt.
} 